\title{
Co-existing mild Hemophilia A with Mild Type 1 Von Willebrand Disease: Case Report
}

\author{
Mehmet AKIN, Deniz Yilmaz KARAPINAR, Can BALKAN, Yilmaz AY, Kaan KAVAKLI
}

EgeUniversity Faculty of Medicine, Department of Pediatric Hematology, Izmir, TURKEY

\begin{abstract}
Von Willebrand disease and haemophilia A are the two most common inherited bleeding disorders. The worldwide incidence of VWD is estimated between $1 \%$ and $4 \%$ of the population without apparent racial or ethnic predilection.

In the United States, the incidence of haemophilia A is estimated to be 25 per 100000 male births. Despite the relatively high frequency of those two bleeding disorders in the general population, the reports of their coexistence together or of combined coagulopathies in general are rare. We describe 1- year old male who was admitted to our hospital with a excessive bleeding after circumcision. Results: Laboratory evaluation revealed a prolonged activated partial thromboplastin time 46.2 sn (normal range 23.2-34.7) and low FVIII activity level of 5.5\% of normal, von willebrand factor antigen and von willebrand factor ristocetin cofactor activity were also low at \%50 and \%44 of normal, respectively. Factor VIII C2 domain R2304H mutation was found. Conclusions: The propositus was now diagnosed with mild type 1 WWD in addition to mild severity haemophilia A. We believe that the co-existence of VWD and haemophilia A is underappreciated, under-diagnosed, and under-reported, given the fact that these are the two most commonly inherited coagulopathies.
\end{abstract}

Keywords: Haemophilia, Von Willebrand disease

\section{ÖZET}

\section{Hafif Tip von Willebrand Hastalığı ile Hafif Hemofili A Birlikteliği}

von Willebrand hastalığı (VWH) ve hemofili A (HA) en yaygın iki alıtsal kanama bozukluğudur. Dünyadaki vWH sıklığının etnik veya ırksal bir ayrım yapmaksızın \%1-4 arasında olduğu tahmin edilmektedir. Amerika Birleşik Devletlerinde HA görülme sıkliğı ise 100.000 erkek doğumda 25 olarak bildirilmektedir. Genel populasyonda bu iki kanama bozukluğunun nisbeten sık görülmelerine rağmen birbirleriyle birlikte seyretmeleri nadir olarak rapor edilmektedir. Sünnet sonrası aşıı kanama ile kliniğimize başvuran 1 yaşında bir erkek hastada bu birlikteliği tanımladık. laboratuar bulgusu olarak aPTZ: 46.2 saniye (N: 23.2-34.7) ve FVIII: \%5 bulunması yanısıra düşük oranda vWF antijeni (\%50) ve Ricof aktivitesi (\%44) saptandı. Anne ve çocukta FVIII mutasyonu çalışlarak C2 bölgesinde R2304H saptandı. Olguya hemofili A ve hafif tip von Willebrand hastalı̆̆ı (Tip 1) tanısı konuldu. Bu iki hastalığın en yaygın kalıtsal koagulopatiler olduğu göz önüne alındığında daha az bilindiği ve daha az teşhis edildiği ve rapor edildiğine inanıyoruz.

Anahtar Kelimeler: Hemofili, von Willebrand hastalığı 


\section{INTRODUCTION}

Von Willebrand disease and haemophilia A are the two most common inherited bleeding disorders. The worldwide incidence of VWD is estimated between $1 \%$ and $4 \%$ of the population without apparent racial or ethnic predilection. ${ }^{1}$

In the United States, the incidence of haemophilia A is estimated to be 25 per 100000 male births. Von Willebrand disease has been classified into three major subtypes based on the qualitative or quantitative properties of VWF protein. Type 1 VWD is essentially a quantitative synthetic deficiency state of all VWF multimer sizes. ${ }^{2}$ Inherited predominantly in an autosomal manner, VWD is now appreciated to be the most common heritable coagulopathy The clinical presentation of VWD is variable. Haemorrhagic complications in affected individuals typically resemble platelet-type bleeding, i.e. easy bruising, mucocutaneous bleeding, menorrhagia, postpartum bleeding, and haemorrhage with minor surgical procedures. ${ }^{3}$ Despite the relatively high frequency of those two bleeding disorders in the general population, the reports of their coexistence together or of combined coagulopathies in general are rare.

We describe a family in which hemophilia A and VWD were simultaneously present: A boy with both mild hemophilia A and mild type 1 VWD whose mother is a carrier of Hemophilia A and father with a diagnosis of mild type 1 VWD.

\section{CASE REPORT}

1- year old male was admitted to our hospital with a excessive bleeding after circumcision. Laboratory evaluation revealed a prolonged APTT $46.2 \mathrm{sn}$ (normal range 23.2-34.7) and low FVIII activity level of 5.5\% of normal, vWF:Ag and VWF:Rco were also low at $\% 50$ and $\% 44$ of normal, respectively. Serial measures of FVIII activity ranged between $5 \%$ and $6 \%$. Tests were repeated two times and revealed same results. Patients' blood type is A. Blood Type $\mathrm{O}$ is associated with vWF levels approximately $25 \%$ lower than non-0 blood type. In our study, no difference was found between 0 blood type and non-0 blood type in terms of VWF: $\mathrm{Ag}$ levels. ${ }^{4}$

His father and paternal grandfather had a history of epistaxis, prolonged bleeding after shaving and ex- cessive bleeding after circumcision. The laboratory findings of proband's father showed normal aPTT, FVIII: $43 \%$, vWF:Ag: $61 \%$ and vWF:RCo: $62 \%$ and his mother's laboratory results revealed normal aPTT, FVIII: 25\%, vWF:Ag: 77\%, vWF:RCo: $79 \%$.The laboratory tests were also done two times for mother and father and results did not show and difference. Blood sample was stored at $-80^{\circ} \mathrm{C}$ for a maximum period of 2 weeks to detect VWF:RCo, VWF:Ag, FVIII:C levels. Test results was reported as a percentage (\%) of mean normal. VWF:RCo levels (normal ranges: 60-160\%) were detected by aggregometry (Bio / Data Corporation, Horsham, PA, USA). VWF:Ag levels (normal ranges: 60$150 \%$ ) were determined using a latex immunoassay using the STA- Compact analyzer (Diagnostica Stago, Asniéres, France). Factor VIII coagulant (FVIII:C) activity (normal ranges: 50-150\%) was assayed by means of automatic coagulation machines (Sysmex, CA- 1500, Japan) using FVIII deficient plasma.

Platelet function analyses were done in child, father and mother. All responses to agonists -ADP, Collagen, epinephrine and ristocetin- were in the normal ranges in all family members .

It was thought that the mother is a carrier of Hemophilia A or had VWD type $2 \mathrm{~N}$ and father had a diagnosis of VWD type 1. VWF multimer analyses, VWF: FVIII binding assay and mutation analyses for Hemophilia A were done in Antwerp University and the results are reported in Table 1.

We would conclude that his father shows no evidence for VWD in these samples but may have a slight VWD type 1, his mother is a carrier of Haemophilia A with no evidence for VWD. The propositus was now diagnosed with mild type 1 VWD in addition to mild severity haemophilia $\mathrm{A}$.

\section{DISCUSSION}

VWD and hemophilia A are the most common inherited bleeding disorders.; therefore, coagulation defects co-existing with VWD should occur commonly enough to merit increased awareness. The likelihood of co-existing coagulopathies should increase in populations where inter-related marriages are common.

Combined inherited coagulopathies coexisting with VWD are not uncommon and frequently are phe- 
Table1. Von Willebrand disease and Hemophilia-A laboratory data

\begin{tabular}{lllll|}
\hline & Normal range & Father & Mother & Child \\
\hline FVIII:C & $50-150 \%$ & 43 & 25 & 5.5 \\
VWF:Ag & $60-150 \%$ & 61 & 77 & 50 \\
VWF:Rco & $60-150 \%$ & 62 & 79 & 44 \\
VWF:CB & $60-150 \%$ & 51.5 & 85.7 & 55 \\
FVIIIC/VWF:Ag ratio & $1.2-1.7$ & 0.70 & 0.32 & 0.12 \\
VWF:RCo/VWF:Ag ratio & $0.7-1$ & 1.02 & 1.03 & 0.88 \\
VWF:CB/VWF:Ag & & 0.84 & 1.11 & 1.10 \\
VWF-FVIII binding assay & & 0.99 & 0.87 & 1.00 \\
VWF: multimeric composition & normal & normal & normal \\
Genetic Analysis of FVIII Gene & none found & Factor VIII C2 & Factor VIII C2 \\
& & & domain R2304H & domain R2304H \\
& & & mutation & mutation \\
\hline
\end{tabular}

notypically divergent from classical VWD. ${ }^{5} \mathrm{Ha}-$ emophilia $\mathrm{A}$ is the most common congenital coagulopathy to co-exist with VWD. Additional hereditary coagulopathies coexisting with VWD were suspected when coagulation laboratory results atypical for VWD were observed; when family history of bleeding complications did not match the characteristic clinical pattern for VWD; and when the severity and character of bleeding manifestations were out of proportion to those signs and symptoms expected with isolated VWD. Casonato et al. reported one case of haemophilia A associated with VWD type $2 \mathrm{~N}^{6}$ and another case in which mild VWD type 1 co-existed with severe haemophilia A. ${ }^{7}$ Another clinical report ${ }^{8}$ described five families with co-existing haemophilia A and VWD. The authors admitted that the presence of VWD confounded their ability to confirm the carrier status of obligate family members for haemophilia A.

We describe individual with confirmed mild haemophilia A co-existing with mild type 1 VWD. In Turkey, aPTT is rarely checked before circumcision and mild prolongation of aPTT are generally thought to be a result of techical problem. In Turkey aproximately $100 \%$ of boys underwent circumcision. Bleeding following circumcision becomes an important clue for the patients with mild hemophilia especially the boys who is the first son of the family. In comparison, two mutations that we observed to be stable but deficient only in vWF bin- ding function (P2300S and $\mathrm{R} 2304 \mathrm{H})$ are associated with variable and mild disease, respectively.

Replacement therapy for acute haemorrhage was aimed at their haemophilia A and no special adjustments were made for their VWF activities although the preferred FVIII replacement product for their care contains significant amounts of VWF (Haemate- P). The diagnosis of this combined deficiency state was suspected either because of their known family medical histories of coagulopathies, or the unusual pattern of their bleeding complications. Another clue was the presence of an abnormally prolonged bleeding time (10). We believe that the co-existence of VWD and haemophilia A is underappreciated, under-diagnosed, and under-reported, given the fact that these are the two most commonly inherited coagulopathies

Acknowledgements: We thank to Dr Alain Gadisseur,professor in Antwerp University for laboratory testing.

\section{REFERENCES}

1. Rodeghiero F, Castaman G, Dini E. Epidemiological investigation of the prevalence of von Willebrand's disease. Blood 69: 454-9, 1987.

2. Sadler JE. von Willebrand disease type 1: a diagnosis in search of a disease. Blood 101: 2089-2093, 2003. 
3. Favaloro EJ, Bonar R, Kershaw G, et al. Reducing errors in identification of von Willebrand disease: The experience of the Royal college of Pathologists of Australasia Quality Assurance Program. Semin Thromb Hemost 32: 505-513, 2006.

4. Akin M, Karapinar YD, Balkan C, Ay Y, Kavakli K. An Evaluation of the DDAVP Infusion Test With PFA-100 and vWF Activity Assays to Distinguish vWD Types in Children. Clinical and Applied Thrombosis/Hemostasis. 2010; May 11. (Epub ahead of print)

5. Asatiani E and Kessler MC. Multiple congenital coagulopathies co-expressed with Von Willebrand's disease: the experience of Hemophilia Region III Treatment Centers over 25 years and review of the literature. Haemophilia 13: 685-696, 2007.

6. Casonato A, Pontara E, Sartorello F, Gemmati D, Cattini MG, Girolami A. Combined hemophilia A and type 2 von Willebrand_s disease: defect of both factor VIII level and factor VIII binding capacity of von Willebrand factor. Haematologica 86: 1110-1111, 2001.

7. Casonato A, Pontara E, Boscaro M, Dannhauser D, Sartori MT, Girolami A. Combined haemophilia A and type I von Willebrand_s disease: a family study including an evaluation of the effects of DDAVP infusion. Haematologia 25: 57-67, 1993.
8. Miller CH, Hilgartner MW, Harris MB, Bussel JB, Aledort LM. Concurrence of von Willebrand's disease and hemophilia A: Implications for carrier detection and prevalence. Am J Med Genet 24: 83-94, 1986.

9. Spiegel PC, Murphy P,Stoddard BL.Surface-exposed Hemophilic Mutations across the Factor VIII C2 Domain Have Variable Effects on Stability and Binding Activities J Biol Chem 17; 279: 53691-53698, 2004.

10. Nitu-Whalley IC, Hermans C, Lee CA. Prevalence of clotting factor deficiencies in a large population with von Willebrand disease. Thromb Haemost 84: 514$515,2000$.

\section{Correspondence}

Dr. Mehmet AKIN

Ege Üniversitesi Tıp Fakültesi

Pediatrik Hematoloji Anabilim Dalı

Bornova, İzmir / TURKEY

Tel: $\quad$ (+90.232) 3901103

E-mail: drmehmetakin@yahoo.com.tr 